\title{
Characterizing the Cancer Genome in Blood
}

\author{
Sarah-Jane Dawson \\ Divisions of Cancer Medicine and Research, Peter MacCallum Cancer Centre, Melbourne 3000, Australia; \\ Centre for Cancer Research, University of Melbourne, Melbourne 3010, Australia \\ Correspondence: sarah-jane.dawson@petermac.org
}

Cell-free circulating tumor DNA (ctDNA) and circulating tumor cells (CTCs) can be found in the bloodstream of individuals with cancer and are increasingly being explored as biomarkers in various aspects of cancer management. The application of next-generation sequencing (NGS) technologies to ctDNA and CTC analysis are providing new opportunities to characterize the cancer genome from a simple blood test and can facilitate the ease with which tumor-specific genomic changes can be followed over time. The serial analysis of ctDNA and CTCs has enormous potential to provide insights into intratumor heterogeneity and clonal evolution during disease progression, and may ultimately allow noninvasive molecular disease monitoring to guide therapeutic decisions and improve patient outcomes.

\begin{abstract}
The advent of next-generation sequencing (NGS) studies have provided important insights into the role of clonal genome evolution in cancer (Aparicio and Caldas 2013). Cancers evolve during disease progression and under the selective pressure of anticancer therapies. The process of clonal evolution is in part driven by intratumoral heterogeneity and is a dynamic process of subclonal expansion and diversification. Today, the inability to accurately characterize spatial and temporal heterogeneity within tumors is thought to be a main reason for the present-day failure of many cancer treatments. Current technological advances in the detection and characterization of circulating biomarkers (circulating tumor DNA [ctDNA] and circulating tumor cells [CTCs]) are providing new opportunities for treatment tailoring that are based on monitoring tumor evolution in real time. Circulating biomarkers can provide a "liquid biopsy" alternative to tissue biopsies allowing
\end{abstract}

noninvasive tumor genotyping and facilitating the serial analysis of genomic changes from a simple blood test. The application of NGS to ctDNA and CTC analysis has marked potential to aid our understanding of cancer heterogeneity, disease evolution, and metastatic biology. Here I coalesce the most significant recent findings in the field and focus on the promises and challenges in developing these tools for clinical applications.

\section{CIRCULATING TUMOR DNA (ctDNA)}

The identification of cell-free circulating DNA (cfDNA) in the blood was first described in 1948; however, the benefit of measuring circulating nucleic acids for biomarker applications in cancer has only begun to be thoroughly explored in the last decade (Mandel and Metais 1948). The majority of cfDNA is released from hematopoietic cells in healthy individuals and

Editors: W. Richard McCombie, Elaine R. Mardis, James A. Knowles, and John D. McPherson

Additional Perspectives on Next-Generation Sequencing in Medicine available at www.perspectivesinmedicine.org

Copyright (C 2019 Cold Spring Harbor Laboratory Press; all rights reserved; doi: 10.1101/cshperspect.a026880

Cite this article as Cold Spring Harb Perspect Med 2019;9:a026880 


\section{S.-J. Dawson}

the genomic and epigenetic features of cfDNA reflect the genome and epigenome of the cell of origin (Sun et al. 2015; Lehmann-Werman et al. 2016; Snyder et al. 2016). In healthy individuals, the quantity of cfDNA is generally very low $(<10 \mathrm{ng} / \mathrm{mL}$ of plasma) but this can increase by $5-10$ times in patients with malignant disease. Greater amounts of cfDNA are identified in cancer patients compared with those found in healthy controls because of the presence of ctDNA that contains tumor-specific sequences harboring somatic genomic alterations found in a patient's tumor (Anker et al. 1999; Gormally et al. 2007). ctDNA enters the circulation after apoptosis and/or necrosis of tumor cells and is usually fragmented to approximately 160$180 \mathrm{bp}$, which reflects the degradation of DNA into nucleosomal units, which is characteristic of the apoptotic process (Jahr et al. 2001; Stroun et al. 2001; Mouliere et al. 2011). Whereas ctDNA has the potential to be released into the bloodstream from both tumor tissue and the lysis of CTCs, CTCs and ctDNA represent distinct entities, with the literature now showing that despite the absence of detectable CTCs it is still possible to identify ctDNA (Punnoose et al. 2012; Dawson et al. 2013; Bettegowda et al. 2014).

Measuring absolute levels of cfDNA have been investigated for various applications in cancer management; however, elevated levels of nonspecific cfDNA can also be identified in healthy individuals and patients with benign diseases limiting the potential clinical utility (Gormally et al. 2007). In contrast, monitoring tumor-specific genetic aberrations in the form of ctDNA has excellent specificity and the potential to serve as a highly sensitive biomarker for patients with cancer. ctDNA can be detected in a number of various solid malignancies and the fraction of ctDNA can vary greatly from $<0.1 \%$ to $>50 \%$. Whereas levels are higher in patients with advanced cancers, recent studies have shown that ctDNA can be detected in patients with localized disease, supporting the broad applicability of ctDNA as a biomarker across various tumor types and in different stages of disease (Bettegowda et al. 2014).

\section{METHODOLOGIES FOR ANALYSIS OF ctDNA}

The analysis of ctDNA is a challenge requiring extremely sensitive techniques because of the small fraction of tumor-specific DNA present within background levels of normal cfDNA. In early stage disease, the most sensitive analysis techniques are required owing to the small fraction of detectable ctDNA. In patients with advanced malignancies, varied methodological techniques have been successfully used owing to the higher ctDNA fraction, which has allowed more extensive genomic analysis techniques to be applied.

Preanalytical factors can have a notable impact on ctDNA analysis (El Messaoudi et al. 2013). Plasma is favored more than serum and should be processed and stored immediately after blood collection to avoid increases in cfDNA levels because of cell lysis of normal blood cells that might impact relative levels of ctDNA. Using commercially available kits, ctDNA can be extracted from plasma and the analysis can go forward via techniques developed to detect genomic alterations. Progress in genomics technologies is affording excellent opportunities to characterize ctDNA. Types of tumor-specific aberrations that have been followed in plasma include point mutations, chromosomal rearrangements, copy number aberrations, and epigenetic alterations (Fig. 1) (Diehl et al. 2008; Leary et al. 2010, 2012; McBride et al. 2010; Forshew et al. 2012; Chan et al. 2013a,b; Dawson et al. 2013; Murtaza et al. 2013; Carreira et al. 2014; Newman et al. 2014). The types of genomic changes analyzed and the different methodologies used are largely driven by the underlying genomic landscape of each tumor type and the particular clinical application for ctDNA testing.

The standard paradigm to discriminate ctDNA from normal cfDNA involves identification of somatic genomic alterations from tumor tissue, the design of assays to recognize these alterations, and the application of these assays to accurately quantify the amount of ctDNA in plasma using polymerase chain reaction (PCR). The detection of somatic point mutations in 


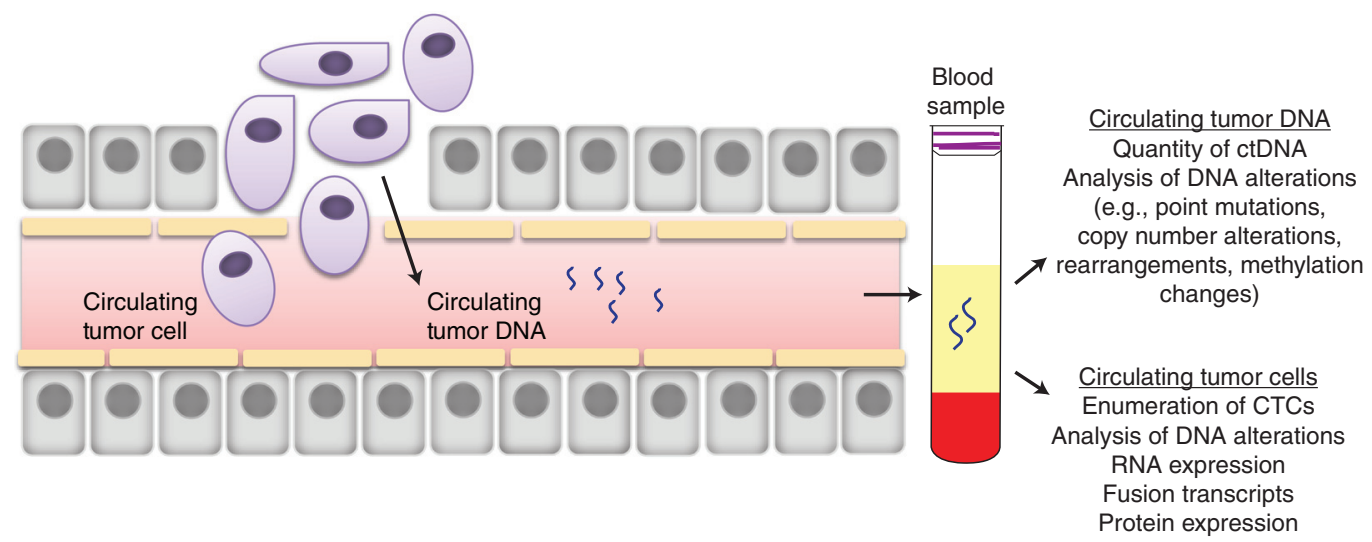

Figure 1. Detection of circulating tumor DNA (ctDNA) and circulating tumor cells (CTCs). Cancers release cellfree ctDNA and CTCs into the bloodstream and these can be used as biomarkers to follow various tumor-specific parameters from a simple blood test in cancer patients.

plasma DNA has been attained via diverse allele-specific PCR and other approaches (Shi et al. 2007; Chen et al. 2009; Board et al. 2010; Sharma et al. 2011; Thierry et al. 2014); however, digital PCR has now emerged as one of the most sensitive analysis tools for ctDNA detection (Vogelstein and Kinzler 1999). Current systematic procedures that involve the use of digital PCR include droplet-based systems (Hindson et al. 2011), microfluidic platforms (Wang et al. 2010), and using beads, emulsions, amplification, and magnetics (BEAMing) (Dressman et al. 2003; Diehl et al. 2008). Digital PCR approaches offer high sensitivity for identifying mutations in ctDNA at low allele fractions (AFs) $(\sim 0.01 \%)$. However, they are most relevant when a finite number of genomic loci are evaluated, for example, the identification of predefined or hot-spot mutations in ctDNA. In parallel to the analysis of somatic point mutations, chromosomal rearrangements (e.g., translocations or gains/losses of chromosomal regions) may also be detected in ctDNA using digital PCR (McBride et al. 2010). Personalized analysis of rearrangement ends (PAREs) is an approach that involves identifying specific somatic rearrangements in tumor tissue and the design of PCR-based assays to recognize these in plasma DNA (Leary et al. 2010). These approaches offer high levels of sensitivity $(\sim 0.001 \%)$ and inherent specificity for ctDNA detection given that the tumor-specific rearrangements are not present in normal cells. However, as with other single-locus PCR-based assays, this approach relies on the initial identification of rearrangements in tumor tissue and limits the ability to track multiple genomic alterations in parallel.

NGS technologies are being increasingly applied to plasma DNA analysis, providing the opportunity to bypass the need for prior analysis of tumor tissue and allowing more comprehensive analysis across larger genomic areas. Targeted deep sequencing using PCR ampliconbased (e.g., Kinde et al. 2011; Forshew et al. 2012; Carreira et al. 2014; Rothe et al. 2014) or hybrid capture (e.g., Newman et al. 2014, 2016; Lanman et al. 2015; Phallen et al. 2017) target enrichment have been used to sequence specified genomic regions in plasma DNA and detect mutations in panels of commonly altered genes across various tumor types. In addition, whole-exome analysis has also been successfully applied to plasma DNA analysis opening up new opportunities to characterize ctDNA without needing to focus on predefined or existing mutations (Murtaza et al. 2013). Finally, in selected cases, whole-genome sequencing (WGS) of plasma DNA has been possible, providing a novel view of chromosomal and copy number aberrations in ctDNA genome-wide (Leary et al. 2012; Chan et al. 2013b; Heitzer et al. 2013b). 
S.-J. Dawson

\section{NEXT-GENERATION SEQUENCING OF CIRCULATING TUMOR DNA}

\section{Targeted Sequencing}

The first NGS approaches to be applied directly to ctDNA analysis have involved the use of targeted deep sequencing to interrogate candidate cancer genes. Target-enrichment strategies have allowed mutations to be identified at low AFs across sizeable genomic regions from a few nanograms of fragmented template from circulating DNA. The most common methods for target enrichment involve (1) highly multiplexed PCR to generate amplicon libraries for sequencing, and (2) hybrid capture using pools of oligonucleotide probes designed to target specific regions of interest from fragment libraries. In contrast to single-locus assays, targeted sequencing approaches allow multiple mutations to be tracked in parallel, providing advantages for tumor monitoring and insights into clonal changes.

Amplicon-based targeted sequencing approaches involve multiplexed PCR for target enrichment followed by deep sequencing, and these approaches have been highly successful for ctDNA analysis across several malignancies (Forshew et al. 2012; Dawson et al. 2013; Murtaza et al. 2013; Carreira et al. 2014; Rothe et al. 2014; Christie et al. 2017; Yeh et al. 2017a,b). Importantly, the success of multiplex PCR strategies for target enrichment relies on the construction of libraries with minimal bias and high levels of molecular complexity. Furthermore, due to the potential for errors to be introduced during the amplification process used for library preparation and the sequencing itself, caution must be observed in calling mutations at low AFs $(<1 \%)$ to avoid false-positive results. In contrast to multiplex PCR strategies, enrichment of genomic regions for targeted sequencing can also be achieved through hybrid capture using oligonucleotides ("capture probes") complementary to the gene regions of interest (Newman et al. 2014; Lanman et al. 2015). Regions of interest for targeted sequencing may range from a few exons through to large regions of the genome, such as the whole exome (Murtaza et al. 2013).

Standard targeted panels for gene sequencing can detect mutations with an $\mathrm{AF}$ of $\sim 1 \%$; however, strategies to reduce background error rates (e.g., through molecular barcoding) have the potential to allow ctDNA to be detected at AFs below $0.1 \%$. Molecular barcoding involves the attachment of unique molecular sequences to each fragment when creating a sequencing library so that reads originating from the same molecule can be identified and PCR or sequencing errors can be corrected (Kinde et al. 2011; Newman et al. 2016; Phallen et al. 2017). In contrast to smaller targeted panels, the utility of whole-exome sequencing for mutation detection from plasma DNA is currently limited by sensitivity, making it most applicable to patients with advanced malignancies, in which the median mutation burden in plasma is $>5 \%$ (Murtaza et al. 2013).

\section{Whole-Genome Sequencing}

For a genome-wide view of tumor DNA in the circulation, WGS can provide a comprehensive analysis of plasma DNA (Leary et al. 2012; Chan et al. 2013b). The sensitivity of WGS approaches is dependent on the overall amount of ctDNA and the level of sequence data obtained. Low-depth or shallow WGS $(\sim 0.1 \times$ coverage $)$ can be used to detect cancer-specific copy number alterations; however, it requires a ctDNA fraction of at least $5 \%-10 \%$, providing limited sensitivity for profiling ctDNA in early-stage disease (Heitzer et al. 2013b).

In contrast to the detection of point mutations using the targeted sequencing approaches described above, substantially more sequencing is needed to detect structural alterations and genome-wide copy number alterations from low levels of DNA using WGS. A sensitivity of ctDNA detection of $\leq 0.1 \%$ is considered necessary to detect patients with potentially curative tumors and, in the short term, targeted sequencing approaches are likely to be most feasible in this context. However, with continued improvements in NGS approaches and ongoing reductions in costs, a variety of NGS techniques will no doubt play an increasing role in ctDNA analysis for prospective clinical applications in patients with both early- and advanced-stage malignancies. 


\section{CIRCULATING TUMOR CELLS}

The development of metastatic disease remains the most significant challenge in the treatment of cancer patients and is responsible for the vast majority of cancer deaths. Metastases begin with the dissemination of single cells (Aceto et al. 2014). Blood represents the hematogenous route for tumor dissemination and studying CTCs offers the promise of providing a better understanding of the biology of metastatic disease. The identifying of CTCs in peripheral blood has been of interest for more than a century when Ashworth (1869) first described a case of cancer in which cells that resembled those in the tumor were seen in blood (Ashworth 1869). CTCs have now been successfully identified in patients before primary tumor detection in early stage cancer and when the carcinoma recurs in the setting of metastatic disease (Allard et al. 2004; Cristofanilli et al. 2004; Almokadem et al. 2005). In some patients, they also appear to persist long after removal of the primary tumor reflecting the possibility of tumor dormancy (Meng et al. 2004). Recent research has focused on the development of improved methods to reproducibly identify tumor cells in the circulation and the application of NGS to CTC molecular analysis.

\section{METHODOLOGIES FOR CTC ISOLATION}

CTCs are uncommon events that occur at a frequency of roughly one tumor cell per $1 \times 10^{7}$ peripheral blood mononuclear cells (Ross et al. 1993). New methodology to identify CTCs needs to distinguish between epithelial and hematopoietic cells in blood and a vast array of technologies have now emerged. These methods generally involve the enrichment of CTCs based on the physical properties of the cells or expression of cell-surface markers, combined with specific CTC identification using immunologic, molecular, or functional methods. The method most widely used for CTC enrichment to date has been immunomagnetic separation based on expression of epithelial cell-adhesion molecule (EpCAM). The semiautomated CellSearch system (Janssen Diagnostics, Raritan, NJ) is based on the enumeration of epithelial cells, which are separated from the blood by EpCAM antibodycoated magnetic beads and then identified with the use of DAPI and fluorescently labeled antibodies to cytokeratins $(8,18$, and 19) (Allard et al. 2004; Riethdorf et al. 2007). The CellSearch system is the only CTC assay to have been fully validated and it has received approval by the U.S. Food and Drug Administration to guide prognosis in patients with metastatic breast cancer, prostate cancer and colorectal cancer (Cristofanilli et al. 2004; Cohen et al. 2008; De Bono et al. 2008; Bidard et al. 2014).

In addition to the CellSearch system, a large number of new technologies are currently in development. The majority of these continue to be based on EpCAM enrichment technologies (e.g., Talasaz et al. 2009; Saucedo-Zeni et al. 2012; Harb et al. 2013; Ozkumur et al. 2013). However, not all CTCs express EpCAM and at least a subset of CTCs undergo epithelialmesenchymal transition (EMT) whereby epithelial markers may be lost or down-regulated (Yu et al. 2013). Alternative technologies that use marker-independent enrichment methods are therefore needed (Marrinucci et al. 2012; Sarioglu et al. 2015; Au et al. 2017). Moreover, single-step methods of CTC enrichment do not isolate a pure population of CTCs, and persistent leukocyte contamination poses significant challenges for downstream molecular profiling. Following CTC enrichment, new technologies are now being developed whereby individual CTCs can be captured, visualized, and isolated for future analysis (e.g., Gascoyne et al. 2009; Fabbri et al. 2013; Ozkumur et al. 2013; Peeters et al. 2013). Although new research platforms will require validation to ensure reproducible sensitivity and achieve diagnostic standards, these technology advances are improving the opportunities for genomic and transcriptomic analysis of this rare cell population.

\section{NEXT GENERATION SEQUENCING ANALYSIS OF CTCS}

\section{CTC Mutational Profiling}

Initial genetic studies involving CTCs were largely performed on DNA extracted from en- 


\section{S.-J. Dawson}

riched CTC populations, and the presence of wild-type DNA from contaminating leukocytes has posed significant challenges. For example, allele-specific PCR-based assays of CTC-enriched cell populations have been used to detect epidermal growth factor receptor (EGFR) mutations in non-small-cell lung cancer (NSCLC); however, some studies have shown poor concordance between tumor biopsies and CTC-derived genotypes owing to limited sensitivity from the presence of leukocyte-derived DNA (Punnoose et al. 2012). These limitations can be overcome if single CTCs are isolated and subjected to genomic analysis. Single-cell CTC analysis provides the opportunity to assess heterogeneity between CTCs and the ability to identify mutations coexistent within a cell. However, single-cell CTC analysis raises new challenges, as a single cell contains only $6.6 \mathrm{pg}$ of DNA. For NGS to be applied for single-cell analysis, whole-genome amplification is required because of the minimal amount of starting material. The amplification must be uniform and reliable, and caution must be taken to ensure that the amplification does not introduce errors or amplification bias that may confound sequencing results (Dean et al. 2002). Furthermore, stringent bioinformatic approaches are required to ensure reliable identification of tumor-specific changes in single CTCs. Single-cell CTC mutational analysis has now been reported in patients with colorectal, lung, and prostate malignancies (Heitzer et al. 2013b; Ni et al. 2013; Lohr et al. 2014). Although still early in development, the prospect of performing single-cell CTC analysis holds great promise to improve our understanding of the function of individual CTCs and how clonal changes evolve over time.

In parallel to the molecular characterization of individual CTCs, intense interest surrounds the use of isolating viable CTCs and using these as a tissue source for functional assays and drug sensitivity testing. CTCs have been cultured ex vivo in patients with breast cancer and activating ESR1 mutations, known to be associated with hormone resistance, have been identified in CTC-derived cell lines from aromatase inhibitor-pretreated estrogen receptor (ER)-positive metastatic breast cancer patients (Yu et al.
2014). In breast cancer and small-cell lung cancer (SCLC), CTCs have been shown to be tumorigenic in immunocompromised mice, confirming that CTC-enriched populations contain tumor-initiating cells (Baccelli et al. 2013; Hodgkinson et al. 2014). In SCLC, the resultant CTC-derived explants have been shown to mirror the underlying tumor in terms of their genomic landscape and patterns of drug sensitivity (Hodgkinson et al. 2014). Furthermore, single-cell WGS of CTCs compared with CTC-derived explants has revealed considerable similarity in terms of copy number profiles.

\section{CTC Gene Expression Profiling}

In parallel to characterizing genomic changes, the ability to assess gene expression in CTCs provides a powerful opportunity to correlate genetic aberrations with specific transcriptional profiles. Early studies of gene expression have used reverse transcription PCR (RT-PCR) to analyze transcripts in CTC-enriched populations. In these studies, digital subtraction of background signal from leukocytes has been essential to derive CTC-based expression signatures. More recently, isolation of single CTCs and analysis of single-cell transcription profiles using NGS technologies has been adopted. In an effort to overcome some of the technical challenges associated with generating expression profiles from single cells, Ramskold et al. (2012) developed a novel messenger RNA sequencing (mRNA-Seq) protocol demonstrating improved read coverage, sensitivity, and reproducibility, compared with standard RNA sequencing. They applied their methodology to the analysis of melanoma CTCs, revealing that highly expressed transcripts were consistently and accurately discovered in the CTCs and that these were similar to the gene expression profiles of melanocytes and melanoma cell lines, yet different in nature from that of leukocytes.

In patients with metastatic prostate cancer, Cann et al. (2012) similarly showed the ability to perform mRNA-Seq on isolated single CTCs. In this study, the RNA from patient CTCs showed signs of significant degradation consistent with 
Characterizing the Cancer Genome in Blood

reports of apoptosis among CTCs; however, despite this, tumor-specific transcriptional profiles were still readily detectable. RNA sequencing has also been successfully applied to analyze CTCs enriched from patients with pancreatic cancer, single CTCs isolated from prostate cancer patients, and viable CTCs cultured ex vivo from patients with breast cancer (Yu et al. 2012, 2014; Ting et al. 2014; Miyamoto et al. 2015). These early studies showed the feasibility of NGS in CTC analysis and highlighted the potential of using CTC genomic and transcriptomic profiles to improve our understanding of cancer heterogeneity. Currently, the number of CTCs that would need to be analyzed to provide a global representation of the underlying tumor is uncertain and may vary across tumor type. However, these approaches undoubtedly hold great promise to provide important biological insights into the metastatic process.

\section{CLINICAL APPLICATIONS OF ctDNA AND CTC ANALYSIS}

The application of NGS approaches to ctDNA and CTC analysis are currently continuing to evolve (Fig. 2). Although the investigation of ctDNA and CTCs present multiple technical hurdles, continuing refinements are expected in the near future, and both approaches hold major promise as biomarkers in cancer management. In time, it is possible that ctDNA and CTCs will have complementary roles, although separate approaches may be advantageous in certain clinical contexts. ctDNA analysis is desirable because of the ease with which plasma can be analyzed without needing to enrich and isolate a rare population of cells. Genomic study of ctDNA can be applied as a high-throughput strategy for analysis of clinical samples, but it is limited in the scrutiny of point mutations, struc-

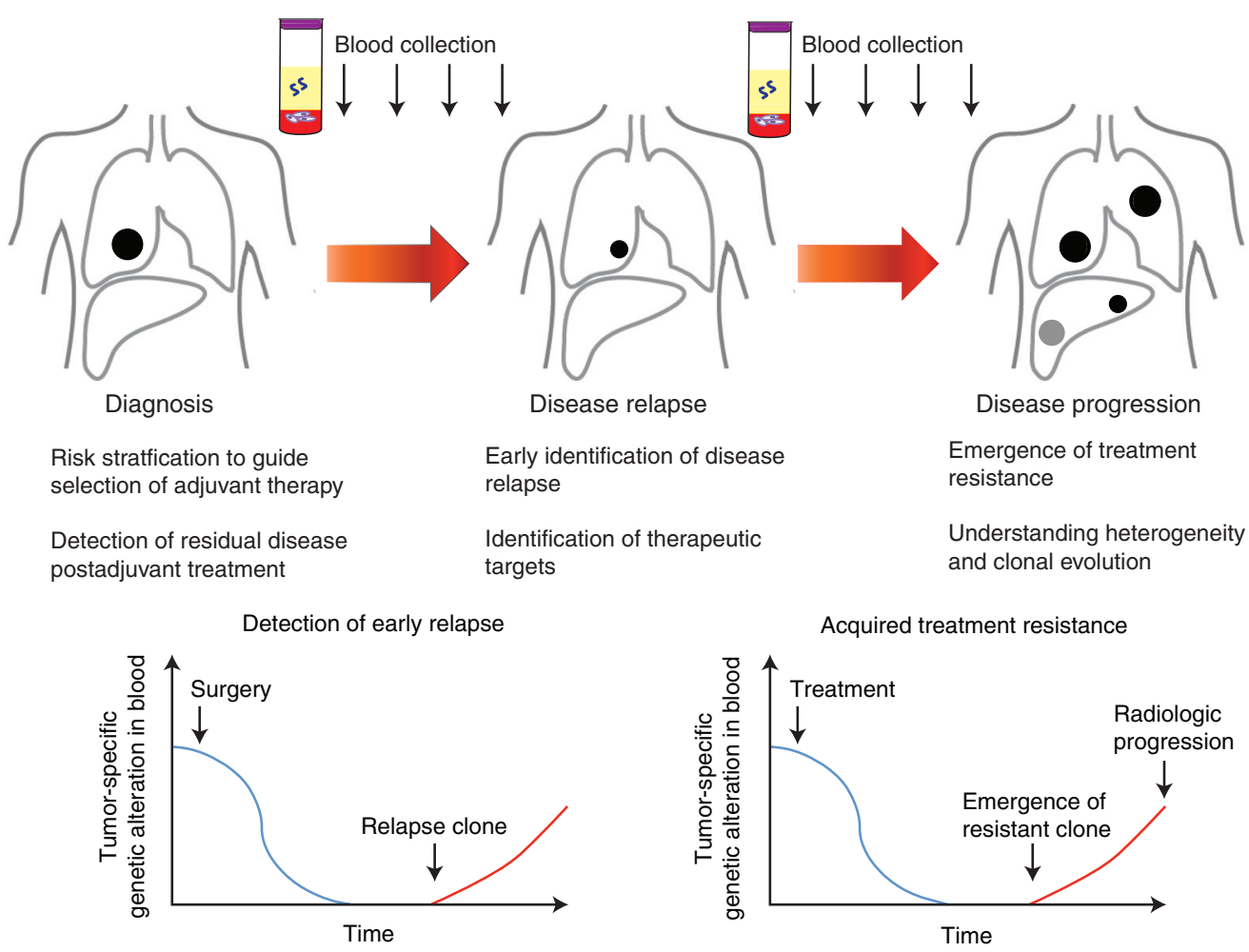

Figure 2. Potential clinical applications of ctDNA and CTCs. The analyses of ctDNA and CTCs have potential to be used in multiple facets of cancer management to guide clinical decisions at the time of diagnosis, disease relapse, and throughout disease progression and treatment. 


\section{S.-J. Dawson}

tural rearrangements, copy number alterations, and DNA methylation. Contrastingly, detailed examination of CTCs brings a special opportunity to investigate the whole cell, allowing DNAand RNA-based molecular profiling, as well as functional studies for modeling personalized treatment selection. The most promising technology platforms to isolate CTCs are currently not widely available, and future standardization and validation of these approaches will be needed for CTC analysis to be more widely adopted for clinical applications.

\section{Tumor Genotyping: Tissue versus Liquid Biopsy}

Studies characterizing the genomic landscape of various malignancies have emphasized the diversity in cancer genomes and the importance of spatial and temporal intratumor heterogeneity (Gerlinger et al. 2012; Nik-Zainal et al. 2012). The sampling of a single region through a tumor biopsy limits the extent to which the complete spectrum of mutations can be assessed. Moreover, serial sampling of tumor material through repeated biopsies is often not possible and hampers efforts to understand genomic evolution during progression and treatment of disease. Current reports suggest that somatic mutations identified in ctDNA and CTCs are largely representative of the underlying tumor genome, providing an alternate noninvasive procedure of tumor sampling that may overcome these limitations (Chan et al. 2013b; Heitzer et al. 2013a; Murtaza et al. 2013; Ni et al. 2013; De Mattos-Arruda et al. 2014; Hodgkinson et al. 2014; Lohr et al. 2014; Rothe et al. 2014; Savas et al. 2016; Yeh et al. 2017a).

An immediate clinical application of this tactic is in identifying specific genomic alterations to steer selected therapies (e.g., EGFR mutations and EML4-ALK rearrangements in NSCLC, BRAF mutations in melanoma, KRAS mutations in colorectal cancer, and HER2 amplification and PIK3CA mutations in breast cancer) (Higgins et al. 2012; Misale et al. 2012; Oxnard et al. 2016; Santiago-Walker et al. 2016). The ability to perform blood-based tumor genotyping assays from ctDNA or CTCs will facilitate which thera- peutic targets can be identified in patients and guide treatment decisions, and, importantly, also permit real-time monitoring during disease progression and therapy (Schwaederle et al. 2016a,b). With development of future genotype-driven therapies, clinical applications in this area will most likely increase in the coming years.

\section{Monitoring Tumor Burden and Therapeutic Responses}

CTC numbers as assessed by the CellSearch system have been used to provide information on tumor burden and treatment response in several solid malignancies. CTC numbers are highly prognostic in patients with metastatic breast (Cristofanilli et al. 2004), colorectal (Cohen et al. 2008), and prostate cancer (De Bono et al. 2008), and, when followed longitudinally, changes in CTC numbers have also been shown to be a marker of treatment response (Bidard et al. 2014). However, CTC enumeration alone provides no additional information on the molecular profile of the cells and the application of NGS to CTC analysis will provide improved opportunities for molecular disease monitoring in the future.

Recent studies have examined ctDNA dynamics in an analogous fashion, investigating the relationship between ctDNA levels, tumor burden, and treatment response (Diehl et al. 2008; Yung et al. 2009; Leary et al. 2010; McBride et al. 2010; Dawson et al. 2013; Bettegowda et al. 2014; Gray et al. 2015; Roschewski et al. 2015). Levels of ctDNA in plasma closely correlate with tumor size and disease stage (Bettegowda et al. 2014). Following treatment, dynamic changes in ctDNA levels reveal changes in tumor burden, and increases in ctDNA often predate detection of progressive disease using radiological methods by several months (Diaz et al. 2012; Dawson et al. 2013; Parkinson et al. 2016). Quantitative analysis of ctDNA may prove to be an important measure of outcome. Initial data has reinforced an association between ctDNA levels and prognosis in patients who have advanced disease (Dawson et al. 2013; Nygaard et al. 2013; Santiago-Walker et al. 2016), but future studies will be required to support the role of ctDNA as a surrogate biomarker 
for disease-free and overall survival in larger patient populations.

A significant hurdle cancer patients face is the development of resistance to chemotherapeutic and targeted agents. This represents another area in which ctDNA and CTC analyses may play a key role. Resistance is in part developed because of an evolving spectrum of somatic mutations within the tumor under the selective pressure of treatment. Current research has shown that ctDNA and CTC analysis can detect emerging mutations associated with treatment resistance, which includes the identification of T790M-EGFR mutations in NSCLC (Maheswaran et al. 2008; Murtaza et al. 2013; Oxnard et al. 2014; Chabon et al. 2016), KRAS mutations and mesenchymal-epithelial transition factor $(M E T)$ amplification in colorectal cancer patients receiving EGFR-based therapies (Diaz et al. 2012; Misale et al. 2012, 2014; Bardelli et al. 2013; Siravegna et al. 2015), the development of ESR1 mutations in hormone-resistant breast cancer (Yu et al. 2014; Schiavon et al. 2015), and the development of androgen receptor mutations and copy number changes, as well as the androgen receptor splice variant 7 (ARV7) in patients receiving treatment for advanced prostate cancer (Carreira et al. 2014; Romanel et al. 2015; Scher et al. 2016). The application of serial ctDNA analysis through NGS of plasma DNA has also been shown to provide a comprehensive and unbiased assessment of genomic changes and tumor evolution during the acquisition of treatment resistance (Murtaza et al. 2013, 2015; Chabon et al. 2016; Scherer et al. 2016; Abbosh et al. 2017; Yeh et al. 2017b). Furthermore, the ability to isolate viable CTCs, culture CTCs ex vivo, and generate CTC-derived xenograft mouse models is opening up a vast array of new opportunities to perform drug sensitivity testing and study drug resistance mechanisms to guide personalized treatment approaches (Hodgkinson et al. 2014; Yu et al. 2014).

\section{Early Detection and Monitoring Minimal Residual Disease}

In hematological malignancies, assessing recurrent genomic alterations such as the $B C R-A B L$ and $P M L-R A R \alpha$ translocations, are routinely used as biomarkers to monitor minimal residual disease (Bregni et al. 1989; Hughes et al. 2006). For solid malignancies, tumor-specific genomic alterations identified on an individual basis could be used to guide clinical management in an analogous fashion. ctDNA and CTC analyses have the possibility to be useful as biomarkers following curative treatment to identify patients who may be at risk of relapsing. Earlier literature has shown that monitoring tumor-specific mutations in plasma following surgical resection, can allow individuals with residual disease to be identified and preemptively detect disease recurrence (Diehl et al. 2008; Chen et al. 2009; Garcia-Murillas et al. 2015; Olsson et al. 2015; Reinert et al. 2016; Tie et al. 2016). Early diagnosis of relapse, while disease burden is minimal, may allow the introduction of additional effective treatments. Conversely, ctDNA or CTCs may assist in stratifying those patients at highest risk of relapse to guide the most appropriate selection of adjuvant therapy. Following treatment for early-stage malignancies, additional research will be necessary to characterize the relationship between ctDNA, CTCs, and disease outcomes.

Last, the potential use of ctDNA or CTCs as biomarkers for cancer screening is one of the most challenging future applications, requiring the highest levels of sensitivity, specificity, and reproducibility to achieve this goal. Ongoing technological advancements may lead to the application of these approaches as screening tools to allow early identification of malignancy at a stage when curative treatments can be offered (Gormally et al. 2006; Beaver et al. 2014; Cohen et al. 2016; Phallen et al. 2017).

\section{CONCLUDING REMARKS}

Cancers evolve during disease progression and under the selective pressure of therapy and our ability to continually monitor tumor-related changes over time will be critical in future cancer management to select optimal treatment regimens. The application of NGS to ctDNA and CTC analysis is providing a one-of-a-kind opportunity to facilitate personalized treatment 


\section{S.-J. Dawson}

decisions by allowing patient-specific genomic changes to be monitored in real time via a minimally invasive technique. Although circulating biomarkers hold great promise in cancer management, substantial effort is still required to understand their clinical application in various contexts. Future research needs to focus on optimizing and standardizing NGS technologies for both ctDNA and CTC analysis and establishing the clinical utility of ctDNA and CTC testing through appropriately designed prospective clinical trials.

\section{ACKNOWLEDGMENTS}

Associate Professor Sarah-Jane Dawson is supported by an Australian National Breast Cancer Foundation and Victorian Cancer Agency Fellowship and CSL Centenary Fellowship.

\section{REFERENCES}

Abbosh C, Birkbak NJ, Wilson GA, Jamal-Hanjani M, Constantin T, Salari R, Le Quesne J, Moore DA, Veeriah S, Rosenthal R, et al. 2017. Phylogenetic ctDNA analysis depicts early-stage lung cancer evolution. Nature 545: 446-451.

Aceto N, Bardia A, Miyamoto DT, Donaldson MC, Wittner BS, Spencer JA, Yu M, Pely A, Engstrom A, Zhu H, et al. 2014. Circulating tumor cell clusters are oligoclonal precursors of breast cancer metastasis. Cell 158: 1110-1122.

Allard WJ, Matera J, Miller MC, Repollet M, Connelly MC, Rao C, Tibbe AG, Uhr JW, Terstappen LW. 2004. Tumor cells circulate in the peripheral blood of all major carcinomas but not in healthy subjects or patients with nonmalignant diseases. Clin Cancer Res 10: 6897-6904.

Almokadem S, Leitzel K, Harvey H, Bannon E, Ali S. 2005. Circulating tumour cells in adjuvant breast cancer patients. J Clin Oncol 23: 667.

Anker P, Mulcahy H, Chen XQ, Stroun M. 1999. Detection of circulating tumour DNA in the blood (plasma/serum) of cancer patients. Cancer Metastasis Rev 18: 65-73.

Aparicio S, Caldas C. 2013. The implications of clonal genome evolution for cancer medicine. New Eng J of Med 368: $842-851$

Ashworth T. 1869. A case of cancer in which cells similar to those in the tumours were seen in the blood after death. Aus Med J 14: 146-149.

Au SH, Edd J, Stoddard AE, Wong KHK, Fachin F, Maheswaran S, Haber DA, Stott SL, Kapur R, Toner M. 2017. Microfluidic isolation of circulating tumor cell clusters by size and asymmetry. Sci Rep 7: 2433.

Baccelli I, Schneeweiss A, Riethdorf S, Stenzinger A, Schillert A, Vogel V, Klein C, Saini M, Bauerle T, Wallwiener M, et al 2013. Identification of a population of blood circulating tumor cells from breast cancer patients that initiates metastasis in a xenograft assay. Nat Biotechnol 31: 539-544.

Bardelli A, Corso S, Bertotti A, Hobor S, Valtorta E, Siravegna G, Sartore-Bianchi A, Scala E, Cassingena A, Zecchin D, et al. 2013. Amplification of the MET receptor drives resistance to anti-EGFR therapies in colorectal cancer. Cancer Discov 3: 658-673.

Beaver JA, Jelovac D, Balukrishna S, Cochran R, Croessmann S, Zabransky DJ, Wong HY, Toro PV, Cidado J, Blair BG, et al. 2014. Detection of cancer DNA in plasma of patients with early-stage breast cancer. Clin Cancer Res 20: $2643-$ 2650 .

Bettegowda C, Sausen M, Leary RJ, Kinde I, Wang Y, Agrawal N, Bartlett BR, Wang H, Luber B, Alani RM, et al. 2014. Detection of circulating tumor DNA in earlyand late-stage human malignancies. Sci Transl Med 6: $224 \mathrm{ra} 24$.

Bidard FC, Peeters DJ, Fehm T, Nole F, Gisbert-Criado R, Mavroudis D, Grisanti S, Generali D, Garcia-Saenz JA, Stebbing J, et al. 2014. Clinical validity of circulating tumour cells in patients with metastatic breast cancer: A pooled analysis of individual patient data. Lancet Oncol 15: 406-414.

Board RE, Wardley AM, Dixon JM, Armstrong AC, Howell S, Renshaw L, Donald E, Greystoke A, Ranson M, Hughes A, et al. 2010. Detection of PIK3CA mutations in circulating free DNA in patients with breast cancer. Breast Cancer Res Treatment 120: 461-467.

Bregni M, Siena S, Neri A, Bassan R, Barbui T, Delia D, Bonadonna G, Dalla Favera R, Gianni AM. 1989. Minimal residual disease in acute lymphoblastic leukemia detected by immune selection and gene rearrangement analysis. J Clin Oncol 7: 338-343.

Cann GM, Gulzar ZG, Cooper S, Li R, Luo S, Tat M, Stuart S, Schroth G, Srinivas S, Ronaghi M, et al. 2012. mRNA-Seq of single prostate cancer circulating tumor cells reveals recapitulation of gene expression and pathways found in prostate cancer. PloS ONE 7: e49144.

Carreira S, Romanel A, Goodall J, Grist E, Ferraldeschi R, Miranda S, Prandi D, Lorente D, Frenel JS, Pezaro C, et al 2014. Tumor clone dynamics in lethal prostate cancer. Sci Transl Med 6: $254 \mathrm{ra125}$

Chabon JJ, Simmons AD, Lovejoy AF, Esfahani MS, Newman AM, Haringsma HJ, Kurtz DM, Stehr H, Scherer F Karlovich CA, et al. 2016. Circulating tumour DNA profiling reveals heterogeneity of EGFR inhibitor resistance mechanisms in lung cancer patients. Nat Commun 7: 11815 .

Chan KC, Jiang P, Chan CW, Sun K, Wong J, Hui EP, Chan SL, Chan WC, Hui DS, Ng SS, et al. 2013a. Noninvasive detection of cancer-associated genome-wide hypomethylation and copy number aberrations by plasma DNA bisulfite sequencing. Proc Natl Acad Sci 110: 18761-18768.

Chan KC, Jiang P, Zheng YW, Liao GJ, Sun H, Wong J, Siu SS, Chan WC, Chan SL, Chan AT, et al. 2013b. Cancer genome scanning in plasma: Detection of tumor-associated copy number aberrations, single-nucleotide variants, and tumoral heterogeneity by massively parallel sequencing. Clin Chem 59: 211-224.

Chen Z, Feng J, Buzin CH, Liu Q, Weiss L, Kernstine K, Somlo G, Sommer SS. 2009. Analysis of cancer mutation signatures in blood by a novel ultra-sensitive assay: Mon- 
itoring of therapy or recurrence in non-metastatic breast cancer. PloS ONE 4: e7220.

Christie EL, Fereday S, Doig K, Pattnaik S, Dawson SJ, Bowtell DDL. 2017. Reversion of BRCA1/2 germline mutations detected in circulating tumor DNA from patients with high-grade serous ovarian cancer. J Clin Oncol 35: 1274-1280.

Cohen SJ, Punt CJ, Iannotti N, Saidman BH, Sabbath KD, Gabrail NY, Picus J, Morse M, Mitchell E, Miller MC, et al. 2008. Relationship of circulating tumor cells to tumor response, progression-free survival, and overall survival in patients with metastatic colorectal cancer. J Clin Oncol 26: 3213-3221.

Cohen PA, Flowers N, Tong S, Hannan N, Pertile MD, Hui L. 2016. Abnormal plasma DNA profiles in early ovarian cancer using a non-invasive prenatal testing platform: Implications for cancer screening. BMC Med 14: 126.

Cristofanilli M, Budd GT, Ellis MJ, Stopeck A, Matera J, Miller MC, Reuben JM, Doyle GV, Allard WJ, Terstappen LW, et al. 2004. Circulating tumor cells, disease progression, and survival in metastatic breast cancer. $N$ Engl $J$ Med 351: 781-791.

Dawson SJ, Tsui DW, Murtaza M, Biggs H, Rueda OM, Chin SF, Dunning MJ, Gale D, Forshew T, Mahler-Araujo B, et al. 2013. Analysis of circulating tumor DNA to monitor metastatic breast cancer. N Engl J Med 368: 1199-1209.

Dean FB, Hosono S, Fang L, Wu X, Faruqi AF, Bray-Ward P, Sun Z, Zong Q, Du Y, Du J, et al. 2002. Comprehensive human genome amplification using multiple displacement amplification. PNAS 99: 5261-5266.

De Bono JS, Scher HI, Montgomery RB, Parker C, Miller MC, Tissing H, Doyle GV, Terstappen LW, Pienta KJ, Raghavan D. 2008. Circulating tumor cells predict survival benefit from treatment in metastatic castration-resistant prostate cancer. Clin Cancer Res 14: 6302-6309.

De Mattos-Arruda L, Weigelt B, Cortes J, Won HH, Ng CK, Nuciforo P, Bidard FC, Aura C, Saura C, Peg V, et al. 2014. Capturing intra-tumor genetic heterogeneity by de novo mutation profiling of circulating cell-free tumor DNA: A proof-of-principle. Ann Oncol 25: 1729-1735.

Diaz LA Jr, Williams RT, Wu J, Kinde I, Hecht JR, Berlin J, Allen B, Bozic I, Reiter JG, Nowak MA, et al. 2012. The molecular evolution of acquired resistance to targeted EGFR blockade in colorectal cancers. Nature 486: $537-$ 540.

Diehl F, Schmidt K, Choti MA, Romans K, Goodman S, L M, Thornton K, Agrawal N, Sokoll L, Szabo SA, et al. 2008. Circulating mutant DNA to assess tumor dynamics. Nat Med 14: 985-990.

Dressman D, Yan H, Traverso G, Kinzler KW, Vogelstein B. 2003. Transforming single DNA molecules into fluorescent magnetic particles for detection and enumeration of genetic variations. Proc Natl Acad Sci 100: 8817-8822.

El Messaoudi S, Rolet F, Mouliere F, Thierry AR. 2013. Circulating cell free DNA: Preanalytical considerations. Clinica Chimica Acta 424: 222-230.

Fabbri F, Carloni S, Zoli W, Ulivi P, Gallerani G, Fici P, Chiadini E, Passardi A, Frassineti GL, Ragazzini A, et al. 2013. Detection and recovery of circulating colon cancer cells using a dielectrophoresis-based device: KRAS mutation status in pure CTCs. Cancer Lett 335: 225-231.
Forshew T, Murtaza M, Parkinson C, Gale D, Tsui DW, Kaper F, Dawson SJ, Piskorz AM, Jimenez-Linan M, Bentley D, et al. 2012. Noninvasive identification and monitoring of cancer mutations by targeted deep sequencing of plasma DNA. Sci Transl Med 4: 136ra68.

Garcia-Murillas I, Schiavon G, Weigelt B, Ng C, Hrebien S, Cutts RJ, Cheang M, Osin P, Nerurkar A, Kozarewa I, et al. 2015. Mutation tracking in circulating tumor DNA predicts relapse in early breast cancer. Sci Transl Med 7: 302ra133.

Gascoyne PR, Noshari J, Anderson TJ, Becker FF. 2009. Isolation of rare cells from cell mixtures by dielectrophoresis. Electrophoresis 30: 1388-1398.

Gerlinger M, Rowan AJ, Horswell S, Larkin J, Endesfelder D, Gronroos E, Martinez P, Matthews N, Stewart A, Tarpey $P$, et al. 2012. Intratumor heterogeneity and branched evolution revealed by multiregion sequencing. $N$ Engl J Med 366: 883-892.

Gormally E, Vineis P, Matullo G, Veglia F, Caboux E, Le Roux E, Peluso M, Garte S, Guarrera S, Munnia A, et al. 2006. TP53 and KRAS2 mutations in plasma DNA of healthy subjects and subsequent cancer occurrence: A prospective study. Cancer Res 66: 6871-6876.

Gormally E, Caboux E, Vineis P, Hainaut P. 2007. Circulating free DNA in plasma or serum as biomarker of carcinogenesis: Practical aspects and biological significance. Mutat Res 635: 105-117.

Gray ES, Rizos H, Reid AL, Boyd SC, Pereira MR, Lo J, Tembe V, Freeman J, Lee JH, Scolyer RA, et al. 2015. Circulating tumor DNA to monitor treatment response and detect acquired resistance in patients with metastatic melanoma. Oncotarget 6: 42008-42018.

Harb W, Fan A, Tran T, Danila DC, Keys D, Schwartz M, Ionescu-Zanetti C. 2013. Mutational analysis of circulating tumor cells using a novel microfluidic collection device and qPCR assay. Transl Oncol 6: 528-538.

Heitzer E, Auer M, Gasch C, Pichler M, Ulz P, Hoffmann EM, Lax S, Waldispuehl-Geigl J, Mauermann O, Lackner C, et al. 2013a. Complex tumor genomes inferred from single circulating tumor cells by array-CGH and nextgeneration sequencing. Cancer Res 73: 2965-2975.

Heitzer E, Ulz P, Belic J, Gutschi S, Quehenberger F, Fischereder K, Benezeder T, Auer M, Pischler C, Mannweiler S, et al. 2013b. Tumor-associated copy number changes in the circulation of patients with prostate cancer identified through whole-genome sequencing. Genome Med 5: 30.

Higgins MJ, Jelovac D, Barnathan E, Blair B, Slater S, Powers P, Zorzi J, Jeter SC, Oliver GR, Fetting J, et al. 2012. Detection of tumor PIK3CA status in metastatic breast cancer using peripheral blood. Clin Cancer Res 18: $3462-$ 3469.

Hindson BJ, Ness KD, Masquelier DA, Belgrader P, Heredia NJ, Makarewicz AJ, Bright IJ, Lucero MY, Hiddessen AL, Legler TC, et al. 2011. High-throughput droplet digital PCR system for absolute quantitation of DNA copy number. Anal Chem 83: 8604-8610.

Hodgkinson CL, Morrow CJ, Li Y, Metcalf RL, Rothwell DG, Trapani F, Polanski R, Burt DJ, Simpson KL, Morris K, et al. 2014. Tumorigenicity and genetic profiling of circulating tumor cells in small-cell lung cancer. Nat Med 20: 897-903. 


\section{S.-J. Dawson}

Hughes T, Deininger M, Hochhaus A, Branford S, Radich J Kaeda J, Baccarani M, Cortes J, Cross NC, Druker BJ, et al. 2006. Monitoring CML patients responding to treatment with tyrosine kinase inhibitors: Review and recommendations for harmonizing current methodology for detecting BCR-ABL transcripts and kinase domain mutations and for expressing results. Blood 108: 28-37.

Jahr S, Hentze H, Englisch S, Hardt D, Fackelmayer FO, Hesch RD, Knippers R. 2001. DNA fragments in the blood plasma of cancer patients: Quantitations and evidence for their origin from apoptotic and necrotic cells. Cancer Res 61: 1659-1665.

Kinde I, Wu J, Papadopoulos N, Kinzler KW, Vogelstein B. 2011. Detection and quantification of rare mutations with massively parallel sequencing. Proc Natl Acad Sci 108: 9530-9535.

Lanman RB, Mortimer SA, Zill OA, Sebisanovic D, Lopez R, Blau S, Collisson EA, Divers SG, Hoon DS, Kopetz ES, et al. 2015. Analytical and clinical validation of a digital sequencing panel for quantitative, highly accurate evaluation of cell-free circulating tumor DNA. PLOS ONE 10: e0140712.

Leary RJ, Kinde I, Diehl F, Schmidt K, Clouser C, Duncan C, Antipova A, Lee C, McKernan K, De La Vega FM, et al. 2010. Development of personalized tumor biomarkers using massively parallel sequencing. Sci Transl Med 2: 20ra14.

Leary RJ, Sausen M, Kinde I, Papadopoulos N, Carpten JD, Craig D, O'Shaughnessy J, Kinzler KW, Parmigiani G, Vogelstein B, et al. 2012. Detection of chromosomal alterations in the circulation of cancer patients with wholegenome sequencing. Sci Transl Med 4: 162ra154.

Lehmann-Werman R, Neiman D, Zemmour H, Moss J, Magenheim J, Vaknin-Dembinsky A, Rubertsson S, Nellgard B, Blennow K, Zetterberg H, et al. 2016. Identification of tissue-specific cell death using methylation patterns of circulating DNA. PNAS 113: E1826-E1834.

Lohr JG, Adalsteinsson VA, Cibulskis K, Choudhury AD, Rosenberg M, Cruz-Gordillo P, Francis JM, Zhang CZ, Shalek AK, Satija R, et al. 2014. Whole-exome sequencing of circulating tumor cells provides a window into metastatic prostate cancer. Nat Biotechnol 32: 479-484.

Maheswaran S, Sequist LV, Nagrath S, Ulkus L, Brannigan B, Collura CV, Inserra E, Diederichs S, Iafrate AJ, Bell DW, et al. 2008. Detection of mutations in EGFR in circulating lung-cancer cells. N Engl J Med 359: 366-377.

Mandel P, Metais P. 1948. Les acides nucléiques du plasma sanguin chez l'homme. C R Seances Soc Biol Fil 142: 241243.

Marrinucci D, Bethel K, Kolatkar A, Luttgen MS, Malchiodi M, Baehring F, Voigt K, Lazar D, Nieva J, Bazhenova L, et al. 2012. Fluid biopsy in patients with metastatic prostate, pancreatic and breast cancers. Phys Biol 9: 016003.

McBride DJ, Orpana AK, Sotiriou C, Joensuu H, Stephens PJ, Mudie LJ, Hamalainen E, Stebbings LA, Andersson LC, Flanagan AM, et al. 2010. Use of cancer-specific genomic rearrangements to quantify disease burden in plasma from patients with solid tumors. Genes Chromosomes Cancer 49: 1062-1069.

Meng S, Tripathy D, Frenkel EP, Shete S, Naftalis EZ, Huth JF, Beitsch PD, Leitch M, Hoover S, Euhus D, et al. 2004.
Circulating tumor cells in patients with breast cancer dormancy. Clin Cancer Res 10: 8152-8162.

Misale S, Yaeger R, Hobor S, Scala E, Janakiraman M, Liska D, Valtorta E, Schiavo R, Buscarino M, Siravegna G, et al. 2012. Emergence of KRAS mutations and acquired resistance to anti-EGFR therapy in colorectal cancer. Nature 486: 532-536.

Misale S, Arena S, Lamba S, Siravegna G, Lallo A, Hobor S, Russo M, Buscarino M, Lazzari L, Sartore-Bianchi A, et al. 2014. Blockade of EGFR and MEK intercepts heterogeneous mechanisms of acquired resistance to anti-EGFR therapies in colorectal cancer. Sci Transl Med 6: 224ra26.

Miyamoto DT, Zheng Y, Wittner BS, Lee RJ, Zhu H, Broderick KT, Desai R, Fox DB, Brannigan BW, Trautwein J, et al. 2015. RNA-Seq of single prostate CTCs implicates noncanonical Wnt signaling in antiandrogen resistance. Science 349: 1351-1356.

Mouliere F, Robert B, Arnau Peyrotte E, Del Rio M, Ychou M, Molina F, Gongora C, Thierry AR. 2011. High fragmentation characterizes tumour-derived circulating DNA. PloS ONE 6: e23418.

Murtaza M, Dawson SJ, Tsui DW, Gale D, Forshew T, Piskorz AM, Parkinson C, Chin SF, Kingsbury Z, Wong AS, et al. 2013. Non-invasive analysis of acquired resistance to cancer therapy by sequencing of plasma DNA. Nature 497: 108-112.

Murtaza M, Dawson SJ, Pogrebniak K, Rueda OM, Provenzano E, Grant J, Chin SF, Tsui DW, Marass F, Gale D, et al. 2015. Multifocal clonal evolution characterized using circulating tumour DNA in a case of metastatic breast cancer. Nat Commun 6: 8760 .

Newman AM, Bratman SV, To J, Wynne JF, Eclov NC, Modlin LA, Liu CL, Neal JW, Wakelee HA, Merritt RE, et al. 2014. An ultrasensitive method for quantitating circulating tumor DNA with broad patient coverage. Nat Med 20: 548-554.

Newman AM, Lovejoy AF, Klass DM, Kurtz DM, Chabon JJ, Scherer F, Stehr H, Liu CL, Bratman SV, Say C, et al. 2016. Integrated digital error suppression for improved detection of circulating tumor DNA. Nat Biotechnol 34: 547555.

Ni X, Zhuo M, Su Z, Duan J, Gao Y, Wang Z, Zong C, Bai H, Chapman AR, Zhao J, et al. 2013. Reproducible copy number variation patterns among single circulating tumor cells of lung cancer patients. Proc Natl Acad Sci 110: 21083-21088.

Nik-Zainal S, Van Loo P, Wedge DC, Alexandrov LB, Greenman CD, Lau KW, Raine K, Jones D, Marshall J, Ramakrishna M, et al. 2012. The life history of 21 breast cancers. Cell 149: 994-1007.

Nygaard AD, Garm Spindler KL, Pallisgaard N, Andersen RF, Jakobsen A. 2013. The prognostic value of KRAS mutated plasma DNA in advanced non-small cell lung cancer. Lung Cancer 79: 312-317.

Olsson E, Winter C, George A, Chen Y, Howlin J, Tang MH, Dahlgren M, Schulz R, Grabau D, van Westen D, et al. 2015. Serial monitoring of circulating tumor DNA in patients with primary breast cancer for detection of occult metastatic disease. EMBO Mol Med 7: 1034-1047.

Oxnard GR, Paweletz CP, Kuang Y, Mach SL, O'Connell A, Messineo MM, Luke JJ, Butaney M, Kirschmeier P, Jackman DM, et al. 2014. Noninvasive detection of response 
and resistance in EGFR-mutant lung cancer using quantitative next-generation genotyping of cell-free plasma DNA. Clin Cancer Res 20: 1698-1705.

Oxnard GR, Thress KS, Alden RS, Lawrance R, Paweletz CP, Cantarini M, Yang JC, Barrett JC, Janne PA. 2016. Association between plasma genotyping and outcomes of treatment with osimertinib (AZD9291) in advanced non-small-cell lung cancer. J Clin Oncol 34: 3375-3382.

Ozkumur E, Shah AM, Ciciliano JC, Emmink BL, Miyamoto DT, Brachtel E, Yu M, Chen PI, Morgan B, Trautwein J, et al. 2013. Inertial focusing for tumor antigen-dependent and -independent sorting of rare circulating tumor cells. Sci Transl Med 5: 179ra47.

Parkinson CA, Gale D, Piskorz AM, Biggs H, Hodgkin C, Addley H, Freeman S, Moyle P, Sala E, Sayal K, et al. 2016. Exploratory analysis of TP53 mutations in circulating tumour DNA as biomarkers of treatment response for patients with relapsed high-grade serous ovarian carcinoma: A retrospective study. PLoS Med 13: e1002198.

Peeters DJ, De Laere B, Van den Eynden GG, Van Laere SJ, Rothe F, Ignatiadis M, Sieuwerts AM, Lambrechts D, Rutten A, Van Dam PA, et al. 2013. Semiautomated isolation and molecular characterisation of single or highly purified tumour cells from CellSearch enriched blood samples using dielectrophoretic cell sorting. Br J Cancer 108: 1358-1367.

Phallen J, Sausen M, Adleff V, Leal A, Hruban C, White J, Anagnostou V, Fiksel J, Cristiano S, Papp E, et al. 2017. Direct detection of early-stage cancers using circulating tumor DNA. Sci Transl Med 9: eaan2415.

Punnoose EA, Atwal S, Liu W, Raja R, Fine BM, Hughes BG, Hicks RJ, Hampton GM, Amler LC, Pirzkall A, et al. 2012. Evaluation of circulating tumor cells and circulating tumor DNA in non-small cell lung cancer: Association with clinical endpoints in a phase II clinical trial of pertuzumab and erlotinib. Clin Cancer Res 18: 2391-2401.

Ramskold D, Luo S, Wang YC, Li R, Deng Q, Faridani OR, Daniels GA, Khrebtukova I, Loring JF, Laurent LC, et al. 2012. Full-length mRNA-Seq from single-cell levels of RNA and individual circulating tumor cells. Nat Biotechnol 30: 777-782.

Reinert T, Scholer LV, Thomsen R, Tobiasen H, Vang S, Nordentoft I, Lamy P, Kannerup AS, Mortensen FV, Stribolt K, et al. 2016. Analysis of circulating tumour DNA to monitor disease burden following colorectal cancer surgery. Gut 65: 625-634.

Riethdorf S, Fritsche H, Muller V, Rau T, Schindlbeck C, Rack B, Janni W, Coith C, Beck K, Janicke F, et al. 2007. Detection of circulating tumor cells in peripheral blood of patients with metastatic breast cancer: A validation study of the CellSearch system. Clin Cancer Res 13: 920-928.

Romanel A, Gasi Tandefelt D, Conteduca V, Jayaram A, Casiraghi N, Wetterskog D, Salvi S, Amadori D, Zafeiriou Z, Rescigno P, et al. 2015. Plasma AR and abirateroneresistant prostate cancer. Sci Transl Med 7: 312re10.

Roschewski M, Dunleavy K, Pittaluga S, Moorhead M, Pepin F, Kong K, Shovlin M, Jaffe ES, Staudt LM, Lai C, et al. 2015. Circulating tumour DNA and CT monitoring in patients with untreated diffuse large B-cell lymphoma: A correlative biomarker study. Lancet Oncol 16: 541-549.

Ross AA, Cooper BW, Lazarus HM, Mackay W, Moss TJ, Ciobanu N, Tallman MS, Kennedy MJ, Davidson NE,
Sweet D, et al. 1993. Detection and viability of tumor cells in peripheral blood stem cell collections from breast cancer patients using immunocytochemical and clonogenic assay techniques. Blood 82: 2605-2610.

Rothe F, Laes JF, Lambrechts D, Smeets D, Vincent D, Maetens M, Fumagalli D, Michiels S, Drisis S, Moerman C, et al. 2014. Plasma circulating tumor DNA as an alternative to metastatic biopsies for mutational analysis in breast cancer. Ann Oncol 25: 1959-1965.

Santiago-Walker A, Gagnon R, Mazumdar J, Casey M, Long GV, Schadendorf D, Flaherty K, Kefford R, Hauschild A, Hwu P, et al. 2016. Correlation of BRAF mutation status in circulating-free DNA and tumor and association with clinical outcome across four BRAFi and MEKi clinical trials. Clin Cancer Res 22: 567-574.

Sarioglu AF, Aceto N, Kojic N, Donaldson MC, Zeinali M, Hamza B, Engstrom A, Zhu H, Sundaresan TK, Miyamoto DT, et al. 2015. A microfluidic device for labelfree, physical capture of circulating tumor cell clusters. Nat Methods 12: 685-691.

Saucedo-Zeni N, Mewes S, Niestroj R, Gasiorowski L, Murawa D, Nowaczyk P, Tomasi T, Weber E, Dworacki G Morgenthaler NG, et al. 2012. A novel method for the in vivo isolation of circulating tumor cells from peripheral blood of cancer patients using a functionalized and structured medical wire. Int J Oncol 41: 1241-1250.

Savas P, Teo ZL, Lefevre C, Flensburg C, Caramia F, Alsop K, Mansour M, Francis PA, Thorne HA, Silva MJ, et al. 2016. The subclonal architecture of metastatic breast cancer: Results from a prospective community-based rapid autopsy program "CASCADE." PLoS Med 13: e1002204.

Scher HI, Lu D, Schreiber NA, Louw J, Graf RP, Vargas HA, Johnson A, Jendrisak A, Bambury R, Danila D, et al. 2016. Association of AR-V7 on circulating tumor cells as a treatment-specific biomarker with outcomes and survival in castration-resistant prostate cancer. JAMA Oncol 2: 1441-1449.

Scherer F, Kurtz DM, Newman AM, Stehr H, Craig AF, Esfahani MS, Lovejoy AF, Chabon JJ, Klass DM, Liu CL, et al. 2016. Distinct biological subtypes and patterns of genome evolution in lymphoma revealed by circulating tumor DNA. Sci Transl Med 8: 364ra155.

Schiavon G, Hrebien S, Garcia-Murillas I, Cutts RJ, Pearson A, Tarazona N, Fenwick K, Kozarewa I, Lopez-Knowles E Ribas R, et al. 2015. Analysis of ESR1 mutation in circulating tumor DNA demonstrates evolution during therapy for metastatic breast cancer. Sci Transl Med 7: 313ra182.

Schwaederle M, Husain H, Fanta PT, Piccioni DE, Kesari S, Schwab RB, Banks KC, Lanman RB, Talasaz A, Parker BA, et al. 2016a. Detection rate of actionable mutations in diverse cancers using a biopsy-free (blood) circulating tumor cell DNA assay. Oncotarget 7: 9707-9717.

Schwaederle M, Husain H, Fanta PT, Piccioni DE, Kesari S, Schwab RB, Patel SP, Harismendy O, Ikeda M, Parker BA et al. 2016b. Use of liquid biopsies in clinical oncology: Pilot experience in 168 patients. Clin Cancer Res 22: 5497-5505.

Sharma VK, Vouros P, Glick J. 2011. Mass spectrometric based analysis, characterization and applications of circulating cell free DNA isolated from human body fluids. Int J Mass Spectrometry 304: 172-183. 


\section{S.-J. Dawson}

Shi J, Liu Q, Sommer SS. 2007. Detection of ultrarare somatic mutation in the human TP53 gene by bidirectional pyrophosphorolysis-activated polymerization allele-specific amplification. Hum Mutat 28: 131-136.

Siravegna G, Mussolin B, Buscarino M, Corti G, Cassingena A, Crisafulli G, Ponzetti A, Cremolini C, Amatu A, Lauricella $\mathrm{C}$, et al. 2015. Clonal evolution and resistance to EGFR blockade in the blood of colorectal cancer patients. Nat Med 21: 827.

Snyder MW, Kircher M, Hill AJ, Daza RM, Shendure J. 2016. Cell-free DNA comprises an in vivo nucleosome footprint that informs its tissues-of-origin. Cell 164: 57-68.

Stroun M, Lyautey J, Lederrey C, Olson-Sand A, Anker P. 2001. About the possible origin and mechanism of circulating DNA apoptosis and active DNA release. Clinica Chimica Acta 313: 139-142.

Sun K, Jiang P, Chan KC, Wong J, Cheng YK, Liang RH, Chan WK, Ma ES, Chan SL, Cheng SH, et al. 2015. Plasma DNA tissue mapping by genome-wide methylation sequencing for noninvasive prenatal, cancer, and transplantation assessments. Proc Natl Acad Sci 112: E5503-E5512.

Talasaz AH, Powell AA, Huber DE, Berbee JG, Roh KH, Yu W, Xiao W, Davis MM, Pease RF, Mindrinos MN, et al. 2009. Isolating highly enriched populations of circulating epithelial cells and other rare cells from blood using a magnetic sweeper device. Proc Natl Acad Sci 106: 39703975.

Thierry AR, Mouliere F, El Messaoudi S, Mollevi C, LopezCrapez E, Rolet F, Gillet B, Gongora C, Dechelotte P, Robert B, et al. 2014. Clinical validation of the detection of KRAS and BRAF mutations from circulating tumor DNA. Nat Med 20: 430-435.

Tie J, Wang Y, Tomasetti C, Li L, Springer S, Kinde I, Silliman N, Tacey M, Wong HL, Christie M, et al. 2016. Circulating tumor DNA analysis detects minimal residual disease and predicts recurrence in patients with stage II colon cancer. Sci Transl Med 8: 346ra92.

Ting DT, Wittner BS, Ligorio M, Vincent Jordan N, Shah AM, Miyamoto DT, Aceto N, Bersani F, Brannigan BW,
Xega K, et al. 2014. Single-cell RNA sequencing identifies extracellular matrix gene expression by pancreatic circulating tumor cells. Cell Rep 8: 1905-1918.

Vogelstein B, Kinzler KW. 1999. Digital PCR. Proc Natl Acad Sci 96: 9236-9241.

Wang J, Ramakrishnan R, Tang Z, Fan W, Kluge A, Dowlati A, Jones RC, Ma PC. 2010. Quantifying EGFR alterations in the lung cancer genome with nanofluidic digital PCR arrays. Clin Chem 56: 623-632.

Yeh P, Dickinson M, Ftouni S, Hunter T, Sinha D, Wong SQ, Agarwal R, Vedururu R, Doig K, Fong CY, et al. 2017a. Molecular disease monitoring using circulating tumor DNA in myelodysplastic syndromes. Blood 129: 16851690.

Yeh P, Hunter T, Sinha D, Ftouni S, Wallach E, Jiang D, Chan YC, Wong SQ, Silva MJ, Vedururu R, et al. 2017b. Circulating tumour DNA reflects treatment response and clonal evolution in chronic lymphocytic leukaemia. Nat Commun 8: 14756.

Yu M, Ting DT, Stott SL, Wittner BS, Ozsolak F, Paul S, Ciciliano JC, Smas ME, Winokur D, Gilman AJ, et al. 2012. RNA sequencing of pancreatic circulating tumour cells implicates WNT signalling in metastasis. Nature 487: 510-513.

Yu M, Bardia A, Wittner BS, Stott SL, Smas ME, Ting DT, Isakoff SJ, Ciciliano JC, Wells MN, Shah AM, et al. 2013. Circulating breast tumor cells exhibit dynamic changes in epithelial and mesenchymal composition. Science 339: 580-584.

Yu M, Bardia A, Aceto N, Bersani F, Madden MW, Donaldson MC, Desai R, Zhu H, Comaills V, Zheng Z, et al. 2014. Cancer therapy. Ex vivo culture of circulating breast tumor cells for individualized testing of drug susceptibility. Science 345: 216-220.

Yung TK, Chan KC, Mok TS, Tong J, To KF, Lo YM. 2009. Single-molecule detection of epidermal growth factor receptor mutations in plasma by microfluidics digital PCR in non-small cell lung cancer patients. Clin Cancer Res 15: 2076-2084. 


\title{
$\&_{\mathrm{CSH}}^{\infty} \&$ Cold Spring Harbor

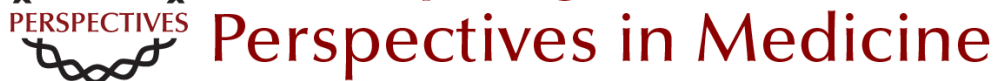

\section{Characterizing the Cancer Genome in Blood}

\author{
Sarah-Jane Dawson
}

Cold Spring Harb Perspect Med 2019; doi: 10.1101/cshperspect.a026880 originally published online May 29, 2018

\section{Subject Collection Next-Generation Sequencing in Medicine}

Next-Generation Sequencing Technologies W. Richard McCombie, John D. McPherson and Elaine R. Mardis

The Impact of Next-Generation Sequencing on Cancer Genomics: From Discovery to Clinic Elaine R. Mardis

Next-Generation Sequencing in Autism Spectrum Disorder Stephan J. Sanders

Sequencing in High Definition Drives a Changing Worldview of the Epigenome Emily Hodges

Whole-Genome Sequencing in Cancer Eric Y. Zhao, Martin Jones and Steven J.M. Jones

\section{High Throughput Sequencing and Assessing} Disease Risk

Shannon M. Rego and Michael P. Snyder

Clinical Versus Research Sequencing Yuriy Shevchenko and Sherri Bale
Single-Cell Applications of Next-Generation Sequencing Naishitha Anaparthy, Yu-Jui Ho, Luciano Martelotto, et al.

Future Promises and Concerns of Ubiquitous Next-Generation Sequencing W. Richard McCombie and John D. McPherson

Next-Generation Sequencing Strategies Shawn E. Levy and Braden E. Boone

Characterizing the Cancer Genome in Blood Sarah-Jane Dawson

The Role of Next-Generation Sequencing in

Pharmacogenetics and Pharmacogenomics Ute I. Schwarz, Markus Gulilat and Richard B. Kim

The Use of Next-Generation Sequencing for Research and Diagnostics for Intellectual

Disability Ricardo Harripaul, Abdul Noor, Muhammad Ayub, et al.

Next-Generation Sequencing and the Return of Results Bartha Maria Knoppers, Minh Thu Nguyen, Karine Sénécal, et al.

For additional articles in this collection, see http://perspectivesinmedicine.cshlp.org/cgi/collection/ 